\title{
Beyond the World, Beyond Significant Language
}

Nuno Venturinha, Lisbon

As is well known, Wittgenstein withdrew from philosophy after the completion of his Tractatus, only resuming work on it when he returned to Cambridge at the beginning of 1929. Then he began to write MS105, the first of a series of "volumes". From 2 to 15 February, following the method used in his 1914-17 notebooks (MSS101-103), he wrote down remarks dealing with philosophy on the right-hand pages and personal remarks on the left-hand ones, but the latter were no longer written in code. From 15 February onwards, however, he left the rest of the left-hand pages blank. These pages he later filled up when he had finished "Volume II", MS106, which shared the structure of MS105, and then started to write "Volume III", MS107, in the conventional way as he did with the remaining volumes. In these, the personal remarks appear interspersed, sometimes written in code and sometimes in normal script, but some of the coded remarks are also philosophical in nature. A nice example of this is provided by two remarks of 10 and 15 November 1929 in the third volume. The first sentence of the former was un-coded, but Wittgenstein crossed it out, rewriting it in code. However, he then added the second sentence in normal script again. The whole paragraph reads as follows:

What is Good is Divine too. That, strangely enough, sums up my ethics. (MS107, 192; CV, 5e)

The second remark, written without any code, says:

You cannot lead people to the good; you can only lead them to some place or other; the good lies outside the space of facts. (MS107, 196; CV, 5e)

These thoughts are not fortuitous; they are closely related to the preparation of Wittgenstein's famous "Lecture on Ethics", given to the Heretics 
Society in Cambridge on 17 November. ${ }^{1}$ This lecture is extremely important for the understanding of Wittgenstein's conception of ethics because it is the only public text after the Tractatus that focuses on this. If it is true that such a topic is recurrent in his manuscripts, it cannot be overlooked that neither Wittgenstein's university lectures nor his typescripts - where he summarized his work for possible publication - bear explicit analyses of it. Why then did Wittgenstein disregard in his "Lecture on Ethics" the silence he proposed in the conclusion of the Tractatus? Should we take the "Lecture on Ethics" as another example of "irony", to follow the "new Wittgensteinians", who read the Tractatus as an ironic dialectic which ethically aims to liberate the reader from all the "laying down of philosophical requirements", using - except in its "frame", the preface and the three concluding remarks - only apparent significant propositions intended to be recognized at the end as "mere nonsense", "plain nonsense"? ${ }^{2}$ Or, as Ray Monk (1990, 276-277) put it, did Wittgenstein simply "use the opportunity to try and correct the most prevalent and serious misunderstanding

${ }^{1}$ There are three versions of it, MSS139a and b, and TS207, the latter being made, according to Brian McGuinness (2002, 157, n. 36), by G. E. M. Anscombe on the basis of MS139b and then published by Rush Rhees in 1965. McGuinness (WVC, 92 , n. 60) conjectures that it may have been a German original. However, that is unlikely first of all because there are two English versions in manuscript and secondly because Wittgenstein gave MS139b to his sister Margarete Stonborough, in all probability the letzter Hand version. For that reason, it seems impossible that TS207 had been prepared by Anscombe based on MS139b since the latter was only rediscovered in 1992 among the Nachlass of Rudolf and Elisabeth Koder to whom Margarete had offered this and other texts shortly after Wittgenstein's death (see Koder 1993). In my opinion, TS207 was prepared by Wittgenstein himself and read at the lecture. Additional evidence is given not only by a note on the top of the first page of TS207 saying "Manuscript von Dr. Ludwig Wittgenstein", probably inserted by Schlick or Waismann with whom the lecture was discussed in 1929-30, but also by a letter from Margarete to Wittgenstein in which she writes: "I was very pleased with your letter. And I am in particular looking forward to your lecture. Something to look forward to. A great joy. [...] And I thank you very much for the manuscript, I could not easily imagine a greater joy." (I have slightly amended Ilse Somavilla's translation in LE 2007, 244. The phrase "Something to look forward to" appears in English in the original, first published in FB, 123.)

2 I am here borrowing expressions from Diamond 1991, 20, and 2000, 149ff. See also, among other texts, Diamond 1991, ch. 6, as well as Conant 2002. 
of the Tractatus: the idea that it is a work written in a positivist, antimetaphysical spirit"? ${ }^{3}$ Let us look at the lecture.

Wittgenstein begins by distinguishing between "trivial or relative sense" and "ethical or absolute sense", trying to show that any expression used to define what is at issue in ethics is, mutatis mutandis, also used to express simple states of affairs (cf. MS139b, 4 (TS 207, 2-3 (LE, 38)), and cp. MS139a, 4). He writes:

If for instance I say that this is a good chair this means that the chair serves a certain predetermined purpose and the word good here has only meaning so far as this purpose has been previously fixed upon. In fact the word good in the relative sense simply means coming up to a certain predetermined standard. (MS 139b, 4-5 (TS 207, 3 (LE, 38)); cp. MS139a, 5)

In fact, we often say that something is good or bad without ascribing to it an ethical or absolute value. As Wittgenstein points out, the condition for something being said to be good (or bad) is only its "coming up [or not] to a certain predetermined standard". Obviously this does not happen only with artefacts, which are by their nature instrumental, but also with living beings, including man himself; it all depends on the work to be performed, which is of course arbitrary. There must be therefore an overlapping of the ethical or the absolute. Wittgenstein actually asks if, unlike what can be the case in a functional performance, which is external, we could approve of someone who recognizes he had behaved badly in this or that situation and at the same time does not want to improve himself at all. The example Wittgenstein gives is the following:

Supposing that I could play tennis and one of you saw me playing and said "well you play pretty badly" and suppose I answered "I know, I'm playing badly but I don't want to play any better".[,] All, [all] the other man could say would be "Ah then that's all right". But suppose I had told one of you a preposterous lie and he came up to me and said "You're behaving like a beast" and then I were to say "I know I behave badly, but then I don't want to behave any better".[,] Would [could] then the man ${ }^{\text {he then }}$ say "Ah, then that's all right"?

${ }^{3}$ Monk's initial words were not chosen incidentally. Cp. MS139b, 1-2 (TS207, 1 (LE, 37)), as well as MS139a, 1-2. 
Certainly not; he would say "well [Well], you ought to want to behave better". (MS139b, 5-6 (TS207, 3 (LE, 38-39)); cp. MS139a, 5-6)

At this point we see that our words touch a sphere which is irreducible to facts, overlapping them. That is to say, there is an event which does not exhaust itself in that event. The problem is: how to describe such an experience? As a matter of fact, what we call ethics immediately vanishes when we objectify the case, i.e. when we express it linguistically, even if it seems that there is no alternative way of expressing it. Wittgenstein puts it extremely forcefully when referring to the possible description of a murder. He remarks:

If for instance [...] we read the description of a murder $<,>$ with all its details physical and psychological the mere description of these facts will contain nothing which we could call an ethical judgement proposition. The murder will be on exactly the same level as any other event, for instance the falling of a stone. Certainly the reading of this description might cause us pain or rage or any other emotion[,] or we might read about the pain or rage caused by this murder in other people when they heard of it, but there will simply be facts, facts $<,>$ and facts but no Ethics. - (MS139b, 8 (TS207, 4-5 (LE, 39-40)); cp. MS139a, 8-9)

The upshot is then obvious: being indescribable, ethics can be no science so that "if it is anything, is supernatural" (cf. MS139b, 9 (TS207, 5 (LE, 40)), and cp. MS139a, 9-10). This idea can also be found in the last entry of 10 November, which comes after the remark quoted in the opening of this paper where Wittgenstein states, in code, that "[o]nly something supernatural can express the Supernatural" (MS107, 192: CV, 5e). Thus is a

${ }^{4}$ In quoting from the Nachlass, I have added to the Normalized transcription offered by the Bergen Electronic Edition some features of the Diplomatic transcription, namely deleted text and indication of insertions. I use square brackets to indicate additions or alterations and angle brackets to indicate suppressions in the typewritten version.

${ }^{5}$ In one of the Vienna Circle conversations from 5 January 1930, recorded by Friedrich Waismann, commenting on his "Lecture on Ethics", Wittgenstein puts the question in the following way: "In ethics our expressions have a double meaning: a psychological one of which you can speak and a non-psychological one [...]. Everything I describe is within the world. An ethical proposition never occurs in the complete description of the world, nor even when I am describing a murderer. What is ethical is not a state of affairs." (WVC, 92-93) 
view like Cora Diamond's right after all, with an ethical proposition being for Wittgenstein nothing but "piggly wiggle tiggle" (cf. Diamond 2000, $153 \mathrm{ff}$.$) ? Or has this "Supernatural" really something to do with us and$ therefore with what we say? Let us take a closer look at the lecture.

In order to be precise about what ethics involves, Wittgenstein presents some experiences of his own, beginning with the one he calls his "experience par excellence", pointing out parenthetically that "this is an entirely personal matter and others would find other examples more striking" (cf. MS139b, 10-11 (TS207, 6 (LE, 41))). ${ }^{6}$ He says:

I believe $F^{t}$ he best way of describing it it to say then I have it $I$ wonder at the existence of the world. And I am then inclined to use such phrases as "how extraordinary that anything should exist" or "how extraordinary that the world should exist".

And he goes on to say:

I will mention an other [another] experience straight away which I also know and which others of you might be acquainted with: it is, what one might call, the experience of feeling absolutely safe. I mean the state of mind in which one is inclined to say "I am safe, nothing can injure me whatever happens". (MS139b, 11 (TS207, 6 (LE, 41)); cp. MS139a, 12)

Wittgenstein would give a third example, that of "feeling guilty", which is "described by the phrase that God disapproves of our conduct" (cf. MS139b, 14 (TS207, 8 (LE, 42)), and cp. MS139a, 15-16), but he concentrates his commentary on the first two. What he points out immediately is that "the verbal expression which we give to these experiences is nonsense", that "[i]f I say 'I wonder at the existence of the world' I am misus-

${ }^{6}$ As McGuinness $(2002,157$, n. 36) rightly argued, the appearance of the phrase "for excellence" in TS207 is surely due to a typing mistake. Cp. MS139a, 11-12. $\mathrm{Cp}$. in addition the following considerations recorded by Waismann from a conversation held on 17 December 1930, in which, after criticizing Moritz Schlick's conception of ethics, Wittgenstein reflects on the concept of "value": "What is ethical cannot be taught. If I could explain the essence of the ethical only by means of a theory, then what is ethical would be of no value whatsoever. I At the end of my lecture on ethics I spoke in the first person. I think that this is something very essential. Here there is nothing to be stated any more; all I can do is to step forth as an individual and speak in the first person. | For me a theory is without value. A theory gives me nothing." (WVC, 117) 
ing language" (cf. MS139b, 11-12 (TS207, 7 (LE, 41)), and cp. MS139a, 12). ${ }^{7}$ Wittgenstein's diagnosis is based, as in the Tractatus, on the bipolarity of the proposition, which requires that for any statement its contrary can also be projected - something that we cannot do in this case. That is only possible in those cases where the falsehood of what we imagine is actually conceivable. What would it be for us to wonder at the non-existence of the world? That cannot be thought indeed. The same also holds true for the statement that we may be "safe whatever happens". Wittgenstein makes the point clear in this passage:

To be safe essentially means that it is physically impossible that certain things should happen to me<,> and therefore it's nonsense to say that I am safe whatever happens. Again this is a misuse of the word "safe" as the other example was a misuse of the word "existence" or "wondering". (MS139b, 13 (TS207, 7 $(\text { LE, 42)) })^{8}$

Nevertheless, an ethical sense remains, exteriorizing what is expressed. We may ask: how do we find this out if the propositions are nonsensical? And the answer is, precisely: through language, through the limits it imposes which we constantly run up against. After introducing the notion of "miracle", examining its "relative" and "absolute" sense, ${ }^{9}$ Wittgenstein (re)describes "the experience of wondering at the existence of the world" in terms of "seeing the world as a miracle", adding that "the right expression in language for the miracle of the existence of the world, though it is not any proposition in language, is the existence of language itself' (cf. MS139b, 17 (TS 207, 9 (LE, pp. 43-44)), and cp. MS139a, 18-19). This "deep sense" does not reduce itself to any propositional content because,

${ }^{7}$ Cp. as well WVC, 93 (5.1.1930): "Astonishment at the fact of the world. Every attempt to express it leads to nonsense."

${ }^{8} \mathrm{Cp}$. MS139a, 14, where Wittgenstein hesitates between "impossible" and "improbable".

${ }^{9}$ Cf. MS139b, 16-17 (TS207, 9 (LE, 43)), and cp. MS139a, 17-18, a passage which includes at the end the following specification: "In the relative sense [the term miracle] simply [means] a hitherto unknown kind of event. Well that's a trivial meaning. But when we are tempted to use it in what I would like to call a deep meaning sense then it means we want it to mean that we wonder at it not because of its ${ }^{\text {the }}$ rarity of what has happened / the event/ but because what has happened has happened whatever has happened." 
Wittgenstein insists, "all we say about the ${ }^{\text {absolute }}$ miraculous remains nonsense" (cf. MS139b, 17 (TS207, 10 (LE, 44)), and cp. MS139a, 19); that is, we cannot turn round the paradoxicality at stake simply by ascribing a meaning to what is nonsensical, just waiting for the day when we will succeed "in finding the correct logical analysis of what we mean by our ethical and religious expressions". ${ }^{10}$ Diamond and her followers are thus perfectly right in arguing that nonsense is nonsense, with the allegories we create corresponding to nothing. What they did not recognize was that the linguistic tension which such expressions give rise to is the manifestation of ethics as the unsayable exteriorization of the self-something that does not happen with "piggly wiggle tiggle", which, not being agrammatical, does not produce any effect. ${ }^{11}$ Wittgenstein's lecture is on ethics, and that is why we understand it. Diamond would go so far as to argue that in reality we remain under the illusion that we understand it, an illusion which Witt-

${ }^{10}$ This passage deserves to be quoted in full: "Now the answer to all this will seem perfectly clear to many of you. You will say: Well, if certain experiences constantly tempt us to attribute a quality to them which we call absolute or ethical value and importance, this simply shews [shows] that by these words we don't mean nonsense, that after all what we mean by saying that an experience has absolute value is just a fact like other facts and that all our difficulties it comes to is $<,>$ that we have not yet succeeded in finding the correct logical analysis of what we mean by our ethical and religious expressions. -" (MS139b, 17-18 (TS 207, 10 (LE, 44)); cp. MS139a, 19-20).

11 A use of language may be agrammatical if, even adopting (apparently) meaningful words, it violates, so to speak, grammar or logical syntax (e.g. "Socrates is identical" or "Chairman Mao is rare", to borrow examples from the Tractatus, $\S \S 5.473$ and 5.4733, and from Dummett 1981, 50-51, respectively), but also if, more than a violation, it produces a real grammatical dissolution which naturally carries with it meaningless expressions. Both cases are different from "piggly wiggle tiggle" in which, besides the meaningless character of its constituent parts, there is no latent grammar as there is, for example, in Lewis Carroll's "Jabberwocky" in Through the Looking-Glass - a poem from which Wittgenstein quoted, in his very first lecture, part of the first verse ("Twas brillig and the slithy toves/ Did gyre and gimble in the wabe") - something that, although it is "nonsense", he says, "can be analysed into subject and predicate and parts of speech" (cf. WL, 3 (20.1.1930)). The sort of dissolution I have drawn attention to can actually be better identified in Antonin Artaud's remarkable "anti-grammatical attempt" to render the first verse of "Jabberwocky" (1979, 140). 
genstein ethically tries to cure us of - a notorious contradiction, which, however, would be necessary to keep until we cease to imagine a content for that. What Wittgenstein elucidates is that the only way in which it makes sense to talk about ethics is one that is for me and that once I have reached such a state I cannot meaningfully say anything of what I am feeling. Nonsense is therefore essential to ethics. ${ }^{12}$ To keep on asking about its sense, obviously revealing its nonsense, so that we may get rid of the "false imagination of philosophy" (cf. Diamond 2000, 169) is ethically worthless. There is no false imagination; what there is, and will keep on being as long as humanity exists, is imagination, in a flash of finitude. Ethics has solely to do with that feeling, "[t]he feeling of the world as a limited whole", i.e. a "mystical feeling", as Wittgenstein put it in $\$ 6.45(2)$ of the Tractatus. The final lines of the lecture where Wittgenstein summarizes his point are clear enough:

My whole tendency and I believe the tendency of all men who ever tried to write or talk Ethics or Religion was to run against the boundaries of language. This running against the walls of our cage is perfectly, absolutely $<,>$ hopeless.-

Ethics, so far as it springs from the desire to say something about the ultimate meaning of life, the absolute good, the absolute valuable[,] can be no science. What it says does not add to our knowledge in any sense. But it is a document of a tendency in the human mind which I personally cannot help respecting deeply and I would not for my life ridicule it. (MS139b, 18-19 (TS207, 10 (LE, 44)); cp. MS139a, 20-21)

Let me then put this alongside Wittgenstein's commentary on Heidegger's Being and Time and/or What is Metaphysics? - a text which derives from the inaugural public lecture given by Heidegger in Freiburg on 24 July 1929 and published in that year - in a conversation from 30 December 1929 recorded by Waismann. He is reported to have said:

${ }^{12}$ With respect to the possible prevalence of sense in "our ethical and religious expressions", namely the ones taken into consideration, Wittgenstein remarks: "[...] these nonsensical expressions were not nonsensical because I had not yet found the correct expressions, but [...] their nonsensicality was their very essence. For all I wanted to do with them was just to go beyond the world and that is to say beyond significant language.” (MS139b, 18 (TS207, 10 (LE, 44)); cp. MS139a, 20) 
To be sure, I can imagine what Heidegger means by being and anxiety. Man feels the urge to run up against the limits of language. Think for example of the astonishment that anything at all exists. This astonishment cannot be expressed in the form of a question, and there is also no answer whatsoever. Anything we might say is a priori bound to be mere nonsense. Nevertheless we do run up against the limits of language. Kierkegaard too saw that there is this running up against something and he referred to it in a fairly similar way (as running up against paradox). This running up against the limits of language is ethics. (WVC, 68) ${ }^{13}$

13 This is the only direct reference by Wittgenstein to Heidegger. Peter Keicher (1998, 83-90; 1999) has insightfully argued that the so-called "Dictation to Schlick" also contains references to Heidegger's philosophy, more specifically to his employment of the phrase "the nothing noths" (das Nichts nichtet) in What is Metaphysics? (cf. TS302, 28ff. (VW, 69ff.)), which is not surprising since the dictation took place after the publication of Carnap's well-known criticism of such a use of language (cf. 1959, 69-73). Who first argued that in the 1929 conversation Wittgenstein has taken into account What is Metaphysics? (and see Heidegger 1998, 88-93) - as well as On the Essence of Ground, also from 1929 - more than Being and Time (published in 1927), was Michael Murray (1978, 81-83). An approach to the discussion from the perspective of Being and Time, via Kierkegaard, is in turn suggested by Thomas Rentsch (2003, 328-330). We shall never know exactly which text Wittgenstein was commenting upon, but, pace Murray (1978, 81-82, n. 6), who considers that "the precise relation between Dread (Angst) and Being (Sein)" constitutes a problem only "taken up directly" by Heidegger in the 1929 texts - even if there is not a single occurrence of the term "anxiety", or "dread", in On the Essence of Ground - we already find in Division Two of Being and Time - a work where two allusions are made to Kierkegaard's The Concept of Anxiety (cf. $\S 40,235$ and 492, n. iv, and $\S 45,278$ and 494, n. vi) - passages like this: "Dasein is authentically itself in the primordial individualization of the reticent resoluteness which exacts anxiety of itself. As something that keeps silent, authentic Being-one's-Self is just the sort of thing that does not keep on saying 'I'; but in its reticence it 'is' that thrown entity as which it can authentically be." (Heidegger 1962, §64, 369-370) Interestingly enough, in Heidegger's so-called "hut copy" of Being and Time, observed in the Gesamtausgabe edition, there is a marginal note inserted after the word "anxiety", which here again translates Angst, saying: "that is, glade of being as being" (d.h. Lichtung des Seins als Seins [sic]) (1977, 322-323). Another striking parallel with Wittgenstein in this passage is the occurrence of " $[a]$ s something that keeps silent", rendering these words als schweigendes, when schweigen is the verb that concludes the Tractatus ("Wovon 
There are two complementary notes from Waismann inserted after the sentence "Nevertheless we do run up against the limits of language". The first evokes, almost literally, $\S 6.45(2)$ of the Tractatus, stating that "[f]eeling the world as a limited whole - it is this that is mystical", ${ }^{14}$ and the other the second ethical experience described in the "Lecture on Ethics", namely that " "[n] othing can happen to me', [that] whatever may happen, for me it is without significance" (WVC, 68, n. I). In this context, the second part of Wittgenstein's commentary on Heidegger is worth quoting:

I think it is definitely important to put an end to all the claptrap about ethics whether intuitive knowledge exists, whether values exist, whether the good is definable. In ethics we are always making the attempt to say something that cannot be said, something that does not and never will touch the essence of the matter. [...] But the inclination, the running up against something, indicate something. St. Augustine knew that already when he said: What, you swine, you want not to talk nonsense! Go ahead and talk nonsense, it does not matter! $(\mathrm{WVC}, 68-69)^{15}$

Richard Rorty - whose philosophical view is in many aspects closely related to Diamond's - has claimed that if " $[\mathrm{t}]$ he early Wittgenstein had defined the mystical as "the sense of the world as a limited whole", translating here the word Gefühl as "sense", "the latter Wittgenstein triumphed

man nicht sprechen kann, darüber muss man schweigen.") Finally, a consideration from Heidegger's postscript to What is Metaphysics? also reveals a close parallelism with Wittgenstein. It reads: "Readiness for anxiety is a Yes to assuming a stance that fulfills the highest claim, a claim that is made upon the human essence alone. Of all beings, only the human being, called upon by the voice of being, experiences the wonder of all wonders: that beings are." (Heidegger 1998a, 234)

${ }^{14}$ In the Tractatus it is said: "The contemplation of the world sub specie aeterni is its contemplation as a limited whole. | The feeling of the world as a limited whole is the mystical feeling."

${ }^{15} \mathrm{Cp}$. WVC, 93 (5.1.1930): "Man has an inclination to run against the limits of language. This running against them signalizes ethics." Cp. as well WVC, 117-118 (17.12.1930), especially Wittgenstein's answer to Waismann's question "Is the existence of the world connected with what is ethical?", which runs as follows: "Men have felt that there is a connection and they have expressed it thus: God the Father created the world, the Son of God (or the Word that comes from God) is that which is ethical. That the Godhead is thought of as divided and, again, as one being indicates that there is a connection here." 
over his younger, more Schopenhauerian self by no longer feeling the need to be mystical, no longer needing to set himself over against the world as 'the unsayable limit of the world" (1991, 50). This image of Wittgenstein's early philosophy is theoretically based, representing the "mystical" for Rorty a will to embrace the whole of reality, as something fixed. His idea is that "[a]s [Wittgenstein] gradually became reconciled to the fact that he would never see the world as a limited whole, he gradually dropped the notion of the "limits of language", which "turned the Tractatus distinction between saying and showing into the distinction between assertions and the social practices which gave meaning to assertions" $(1991,64)$. The pragmatism Rorty has ascribed to the later Wittgenstein - and correlatively to the early Heidegger - is another attempt to reject the (standard) antirealist interpretation, which grew out of Michael Dummett's work, in favour of a complete theoretical abandonment, that is, of a therapy. But it is not, as Rorty believed, the rejection of a realist view, as well as of any other representationalism, no longer "feeling the need to be mystical" and eliminating the saying/showing distinction, that will determine Wittgenstein's post-1929 methodology. Contrary to what Peter Hacker also claims, namely that "[a]fter the 'Lecture on Ethics' of 1929 Wittgenstein wrote nothing further on ethics, save for occasional asides", inasmuch as "the doctrine of the ineffability of absolute value [had been] abandoned" (2001, 167), the re-evaluation of ethics at the end of that year must be taken prospectively, with Wittgenstein's elucidatory work relying precisely on that point of view, as is clearly seen in his manuscripts. An analysis of these, however, would take me well beyond the scope of this paper.

An earlier version of this paper was read at the Heidegger-Wittgenstein Workshop, University of Wales, Lampeter, on 17 November 2007. I wish to thank Edward Harcourt and James Luchte for their comments and the audience on that occasion for stimulating questions. 


\section{Literature}

Artaud, Antonin 1979: "L'Arve et l'Aume: Tentative anti-grammaticale contre Lewis Carroll". In: Cuvres complètes d'Antonin Artaud, vol. 9. Paris: Gallimard, 133-146.

Baker, Gordon (ed.) 2003: The Voices of Wittgenstein: The Vienna Circle. London: Routledge. (VW)

Carnap, Rudolf 1959: "The Elimination of Metaphysics Through Logical Analysis of Language", translated by Arthur Pap. In: Ayer, A. J. (ed.): Logical Positivism. New York: Free Press, 60-81.

Conant, James 2002: "The Method of the Tractatus". In: Reck, Erich. H. (ed.): From Frege to Wittgenstein: Perspectives on Early Analytic Philosophy. Oxford: OUP, 374462.

Diamond, Cora 1991: The Realistic Spirit: Wittgenstein, Philosophy, and the Mind. Cambridge, MA: MIT Press.

Diamond, Cora 2000: "Ethics, imagination and the method of Wittgenstein's Tractatus". In: Crary, Alice / Read, Rupert (eds.): The New Wittgenstein. London: Routledge, 149-173.

Dummett, Michael 1981: Frege: Philosophy of Language. $2^{\text {nd }}$ Edition. London: Duckworth.

Hacker, P. M. S. 2001: Wittgenstein: Connections and Controversies. Oxford: Clarendon Press.

Heidegger, Martin 1962: Being and Time, translated by John Macquarrie and Edward Robinson. Oxford: Blackwell.

Heidegger, Martin 1977: Sein und Zeit, edited by Friedrich-Wilhelm von Hermann. In: Gesamtausgabe, vol. 2. Frankfurt am Main: Vittorio Klostermann.

Heidegger, Martin 1998: "What is Metaphysics?", translated by David Farrell Krell. In: Pathmarks, edited by William McNeill. Cambridge: CUP, 82-96.

Heidegger, Martin 1998a: "Postscript to 'What is Metaphysics?", translated by William McNeill. In: Pathmarks, edited by William McNeill. Cambridge: CUP, 231-238.

Keicher, Peter 1998: "Untersuchungen zu Wittgensteins 'Diktat für Schlick'”. In Krüger, Wilhelm / Pichler, Alois (eds.): Arbeiten zu Wittgenstein. Bergen: Working Papers from the Wittgenstein Archives at the University of Bergen, 43-90.

Keicher, Peter 1999: "Eine Insel des Seins umspült vom unendlichen Meer des Nichts'. Wittgensteins Bemerkungen zu Heidegger". In: Meixner, Uwe / Simons, Peter (eds.): Metaphysics in the Post-Metaphysical Age: Papers of the 22nd International Wittgenstein Symposium, vol. 1. Kirchberg am Wechsel: Austrian Ludwig Wittgenstein Society, 298-304. 
Koder, Johannes 1993: "Verzeichnis der Schriften Ludwig Wittgensteins im Nachlaß Rudolf und Elisabeth Koder”. Mitteilungen aus dem Brenner-Archiv 12, 52-54.

Lee, Desmond (ed.) 1980: Wittgenstein's Lectures: Cambridge, 1930-1932. Oxford: Blackwell. (WL)

McGuinness, Brian (ed.) 1979: Wittgenstein and the Vienna Circle: Conversations recorded by Friedrich Waismann, translated by Joachim Schulte and Brian McGuinness. Oxford: Blackwell. (WVC)

McGuinness, Brian / Ascher, Maria Concetta / Pfersmann, Otto (eds.) 1996: Wittgenstein: Familienbriefe. Vienna: Hölder-Pichler-Tempsky. (FB)

McGuinness, Brian 2002: Approaches to Wittgenstein: Collected papers. London: Routledge.

Monk, Ray 1990: Ludwig Wittgenstein: The Duty of Genius. London: Jonathan Cape.

Murray, Michael 1978: “Ludwig Wittgenstein: On Heidegger on Being and Dread”. In: Murray, Michael (ed.): Heidegger and Modern Philosophy. New Haven: Yale University Press, 80-83.

Rentsch, Thomas 2003: Heidegger und Wittgenstein: Existential- und Sprachanalysen zu den Grundlagen philosophischer Anthropologie. $2^{\text {nd }}$ Edition. Stuttgart: Klett-Cotta.

Rorty, Richard 1991: Essays on Heidegger and others: Philosophical Papers, vol. 2. Cambridge: CUP.

Wittgenstein, Ludwig 1933: Tractatus Logico-Philosophicus. $2^{\text {nd }}$ Edition, trans. by C. K. Ogden. London: Routledge and Kegan Paul.

Wittgenstein. Ludwig 1993: "A Lecture on Ethics", edited with the assistance of Rush Rhees. In: Klagge, J. C. / Nordmann, Alfred (eds.): Ludwig Wittgenstein: Philosophical Occasions 1912-1951. Indianapolis: Hackett, 36-44. (LE)

Wittgenstein, Ludwig 1998: Culture and Value: A Selection from the Posthumous Remains. $2^{\text {nd }}$ Edition, edited by G. H. von Wright in collaboration with Heikki Nyman, revised edition of the text by Alois Pichler, translated by Peter Winch. Oxford: Blackwell. (CV)

Wittgenstein, Ludwig 2000: Wittgenstein's Nachlass: The Bergen Electronic Edition. Oxford: OUP. (MSS \& TSS)

Wittgenstein, Ludwig 2007: Lecture on Ethics: Introduction, Interpretation and Complete Text, edited by Edoardo Zamuner, E. Valentina Di Lascio and David Levy, with notes by Ilse Somavilla. Macerata: Quodlibet. (LE 2007) 